\title{
Interplay between Microorganisms and Geochemistry in Geological Carbon Storage
}

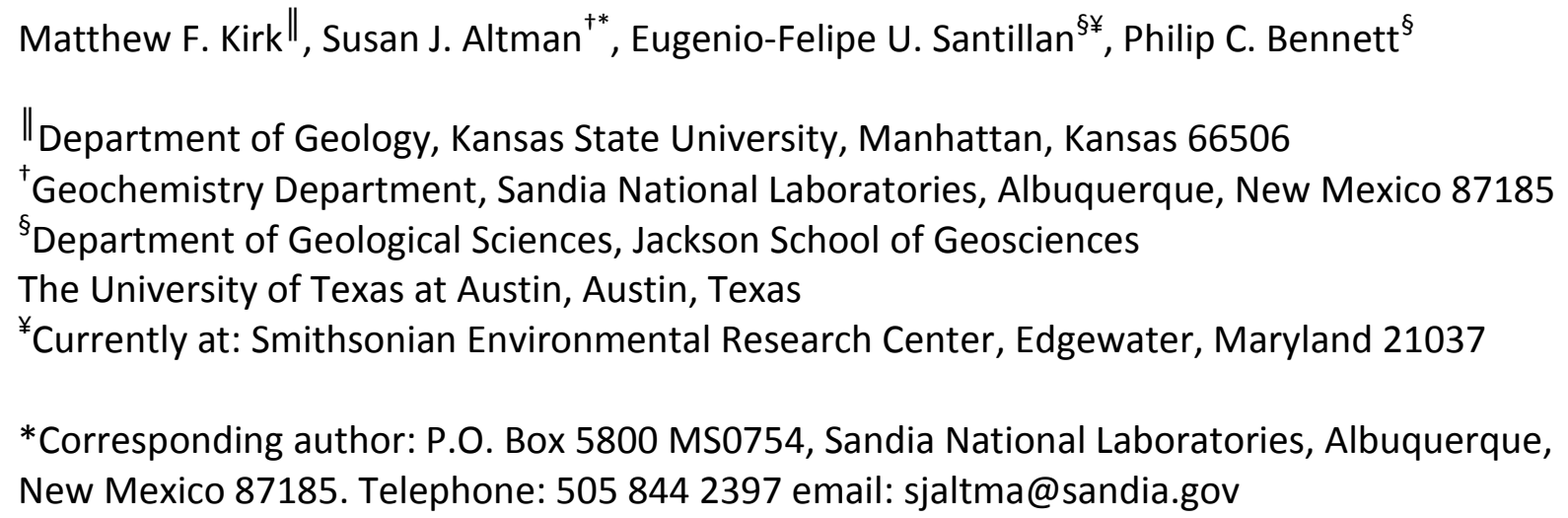

Key words: Carbon trapping, porous media, subsurface microbiology, bioenergetics, capnophile, bioreactor experiments

Classification: Geological storage - By mechanisms, processes and discipline Geological storage - other Geochemical - Coverage/Type 
Researchers at the Center for Frontiers of Subsurface Energy Security (CFSES) have

45 conducted laboratory and modeling studies to better understand the interplay between

46 microorganisms and geochemistry for geological carbon storage (GCS). We provide evidence of

47 microorganisms adapting to high pressure $\mathrm{CO}_{2}$ conditions and identify factors that may

48 influence survival of cells to $\mathrm{CO}_{2}$ stress. Factors that influenced the ability of cells to survive

49 exposure to high-pressure $\mathrm{CO}_{2}$ in our experiments include mineralogy, the permeability of cell

50 walls and/or membranes, intracellular buffering capacity, and whether cells live planktonically

51 or within biofilm. Column experiments show that, following exposure to acidic water, biomass

52 can remain intact in porous media and continue to alter hydraulic conductivity. Our research

53 also shows that geochemical changes triggered by $\mathrm{CO}_{2}$ injection can alter energy available to

54 populations of subsurface anaerobes and that microbial feedbacks on this effect can influence

55 carbon storage. Our research documents the impact of $\mathrm{CO}_{2}$ on microorganisms and in turn, how

56 subsurface microorganisms can influence GCS. We conclude that microbial presence and

57 activities can have important implications on carbon storage and that their presence should not

58 be overlooked in further GCS research.

59 


\section{Introduction}

Geologic carbon storage (GCS) involves the capture, compression, injection, and storage of anthropogenic carbon dioxide $\left(\mathrm{CO}_{2}\right)$ in order to mitigate carbon emissions to the atmosphere. Deep (>1 km below the ground surface) sedimentary formations are one of the largest sets of likely injection targets. Pore waters in potential storage reservoirs are typically saline with ionic strengths ranging from that of seawater to levels near those of fluids saturated with halite. Injected $\mathrm{CO}_{2}$ will exist as a supercritical phase, given the ranges of pressures and temperatures at these depths (10 to $30 \mathrm{MPa}$ and 310 to $380 \mathrm{~K}$ ). High concentrations of dissolved $\mathrm{CO}_{2}$ will alter groundwater $\mathrm{pH}$ and dissolved inorganic carbon (DIC) concentration, increase levels of dissolved ions, and cause both mineral dissolution and precipitation (Kaszuba and Janecky, 2009; Lu et al., 2010).

Benson et al. (2005) describes the four trapping mechanisms for GCS: structural, residual, solubility, and mineral. It is well recognized that these mechanisms are driven by geochemical and hydrological processes. Microbial processes may also be important, however, because microorganisms can influence hydrological and geochemical processes in subsurface environments (Baker et al., 2010; Banks et al., 2010; Davidson et al., 2011; Fredrickson et al., 1998; Gorbushina, 2007; Onstott et al., 1998; Pedersen et al., 1996; Sahl et al., 2008). For example, microbial biomass can enhance precipitation of carbonate minerals (Cunningham et al., 2009; Kandianis et al., 2008; Mitchell et al., 2010), clog porous media (Baveye et al., 1998), and alter water chemistry on a regional scale (Flynn et al., 2013; Kirk et al., 2015).

Microbial life extends deep into the subsurface, including depths of interest to GCS. The depth limit of microbial life in the subsurface is somewhat uncertain. However, active 
82 microorganisms have been confirmed at depths greater than $3 \mathrm{~km}$ (Kieft et al., 2005). Their ability to adapt to a wide range of environmental conditions (Pikuta et al., 2007) together with the vast size of the habitable subsurface allow subsurface microbes to play a major role in mediating global-scale biogeochemical processes (Colwell and D'Hondt, 2013; Orcutt et al., 2013; Parkes et al., 2014).

Changes in conditions following $\mathrm{CO}_{2}$ injection will impose stress on indigenous microorganisms, potentially triggering changes in community composition (Mu et al., 2014; Peet et al., 2015; Wilkins et al., 2014). Where $\mathrm{CO}_{2}$ exists as a supercritical phase, it may dissolve cell membranes and cause cell death (Dillow et al., 1999; White et al., 2006). High levels of $\mathrm{CO}_{2}$ in an aqueous solution can also be toxic to microbes because $\mathrm{CO}_{2}$ can pass through cell membranes, acidify cytoplasm, and disrupt cellular functions (Ballestra et al., 1996).

In addition to changes in community composition driven by $\mathrm{CO}_{2}$ stress, $\mathrm{CO}_{2}$ injection may also shift community composition by altering redox disequilibrium. When $\mathrm{CO}_{2}$ dissolves into water, carbonic acid is produced, which can then dissociate into protons and dissolved inorganic carbon species:

$$
\mathrm{CO}_{2}(a q)+\mathrm{H}_{2} \mathrm{O} \leftrightarrow \mathrm{H}_{2} \mathrm{CO}_{3} \leftrightarrow \mathrm{HCO}_{3}^{-}+\mathrm{H}^{+} \leftrightarrow \mathrm{CO}_{3}^{2-}+2 \mathrm{H}^{+}
$$

Because many of the redox reactions used as a source of energy by microbes include dissolved inorganic carbon species as well as hydrogen ions, changes in $\mathrm{CO}_{2}$ abundance affects the extent to which those reactions are out of equilibrium (Harvey et al., 2013; Kirk, 2011; Mayumi et al., 2013; Ohtomo et al., 2013). Such changes can significantly affect microbial activity because the amount of energy that is available in the environment for microbial reactions affects the ability of microorganisms to compete with one another. Microorganisms that conserve energy from 
more energetically favorable reactions can grow faster, and thus catalyze their reaction more rapidly, than those using less favorable reactions (Jin, 2012; LaRowe and Amend, 2015; Lovley and Goodwin, 1988; Roden and Jin, 2011).

In this paper, we examine geomicrobiological studies conducted at the Center for Frontiers of Subsurface Energy Security (CFSES) within the context of the interplay between microbiology and GCS. In other words, we consider what our findings tell us about how GCS could affect subsurface microbes and in turn, how subsurface microbes could affect GCS. Given the potential for microorganisms to influence the geochemistry and hydrodynamics of the subsurface, understanding this interplay may be a key to ensuring secure carbon storage. Moreover, this knowledge can provide a basis for developing biological strategies to enhance GCS reservoir performance (Mitchell et al., 2010).

CFSES is an Energy Frontier Research Center established by the Office of Science, Basic Energy Sciences program in the U.S. Department of Energy in 2009 and chosen for renewal until 2018. Researchers at CFSES have taken many different approaches to better understand the interplay between GCS and subsurface microbiology. Our research has identified and characterized an isolate from a $\mathrm{CO}_{2}$-rich spring (Santillan et al., 2015). We used pure-culture batch reactor experiments to test the influence of mineralogy on the ability of cells to survive exposure to high-pressure $\mathrm{CO}_{2}$ (Santillan et al., 2013). We considered how decreasing $\mathrm{pH}$, a geochemical change caused by $\mathrm{CO}_{2}$ injection, will affect the stability of bioclogging in porous media (Kirk et al., 2012). And, we used bioenergetics and mixed-community bioreactor experiments to assess potential changes in the relative significance of different microbial processes in response to increasing $\mathrm{CO}_{2}$ abundance (Kirk, 2011; Kirk et al., 2013). These efforts 
126 provide insight into both sides of the two-way interactions between GCS and subsurface

127 microorganisms.

129 2. Methods

The content below provides a brief summary of methods used in our investigations. For

131 more details about these methods as well as our results, please refer back to the publications

132 associated with each study.

133

134

2.1. Isolation

A capnophile, an microbe capable of growth in the presence of high concentrations of

$136 \mathrm{CO}_{2}$, was isolated and characterized as part of our effort to learn about properties of microbes

137 in aqueous environments with high $\mathrm{CO}_{2}$ levels (Santillan et al., 2015). The isolate was collected

138 from Crystal Geyser spring, Utah, USA. The site is considered an analog site for GCS research

139 and provides the opportunity to study a subsurface microbial community that has been

140 exposed to elevated $\mathrm{CO}_{2}$ over a long period of time (Emerson et al., 2015). $\mathrm{CO}_{2}$ has been leaking

141 from the subsurface near the geyser for over 400,000 years (Burnside et al., 2013).

142 Samples of water and microbial biomass were collected at $9.7 \mathrm{~m}$ depth in the spring

143 outlet using aseptic techniques. Cultures were prepared immediately by placing filtered

144 biomass in serum bottles that contained Luria Bertain broth amended with $15 \mathrm{~g} \mathrm{~L}^{-1} \mathrm{NaCl}$. The

145 bottles were then placed within a pressure vessel and pressurized to $1 \mathrm{MPa}$ with ultrapure $\mathrm{CO}_{2}$.

146 Cultures were incubated for about 1 month and then re-cultured multiple times to cultures 
147 containing Tryptic soy broth with $15 \mathrm{~g} \mathrm{~L}^{-1} \mathrm{NaCl}$. After three transfers, the cultures were diluted 148 to extinction to obtain an isolate.

149 The isolate discussed in this paper, designated CG-1, was assessed for growth under 150 various conditions that focused on $\mathrm{CO}_{2}$, temperature, salinity, $\mathrm{pH}$, carbon substrates, electron 151 acceptors, and fermentation capability. Cloning was performed on GC-1 to determine its $16 \mathrm{~S}$ 152 gene identity through the Basic Local Alignment Search Tool search (BLASTn) search 153 (http://blast.ncbi.nlm.nih.gov/). A phylogenetic tree relating the isolate to related sequences 154 was made using CLUSTALX (Chenna et al., 2003). Cell morphology was characterized using 155 transmission electron microscopy (TEM). Lipid samples were processed according to Rodriguez156 Ruiz et al. (1998) and analyzed using gas chromatography mass spectrometry (GCMS).

\subsection{Pure-culture experiments}

Pure-culture experiments were performed to examine factors influencing the ability of

160 cells to survive exposure to high-pressure $\mathrm{CO}_{2}$ (Santillan et al., 2013). Experiments were

161 conducted with three model organisms: Shewanella oneidensis strain MR-1 (ATCC BA-1096),

162 Geobacillus stearothermophilus (ATCC 7953), and Methanothermobacter thermoautitrophicus

163 (ATCC 29096). These organisms allowed the experiments to include variation in metabolic

164 reactions as well as cell wall structure and composition. S. oneidensis is a Gram negative

165 bacterium that was grown under iron-reducing conditions, G. stearothermophilus is a Gram

166 positive aerobic bacterium that is capable of sporulation, and $M$. thermoautitrophicus is a

167 methanogenic archaeaon. Species closely related to G. stearothermophilus and $M$.

168 thermoautitrophicus have been detected in the deep subsurface (Kawaguchi et al., 2010; 
169 Nazina et al., 2001). S. oneidensis is widespread in soils and shallow sediment and has been

170 studied within the context of $\mathrm{CO}_{2}$ leakage to shallow groundwater from deep storage (Wu et al., 171 2010).

Organisms were grown to stationary phase in batch cultures and then placed in pressure

173 vessels (Parr instruments) and exposed to elevated $\mathrm{CO}_{2}$ pressure at $30^{\circ} \mathrm{C}$ for time periods

174 ranging from 1 to $24 \mathrm{hr} . \mathrm{CO}_{2}$ pressures tested ranged from 0.3 to $6.5 \mathrm{MPa}$. At the end of the

175 exposure period, pressure was slowly released over a period of about 2 min to limit potential

176 impacts of pressure change on cell survival. The cultures were then removed from the pressure

177 vessels and sonicated to disperse biofilm and attached cells. Cell survival was quantified using

178 cultivation. Cultivable S. oneidensis and G. stearothermophilus cells were enumerated using the

179 pour plate method. M. thermoautitrophicus cells were was cultivated in liquid anaerobic

180 cultures with low $\mathrm{CO}_{2}$ content. Growth was periodically assessed in the cultures by measuring

181 optical density at $680 \mathrm{~nm}$. Iron reducing activity of S. oneidensis was evaluated by measuring

182 ferrous iron concentration using the ferrozine method (Stookey, 1970). Methanogenesis by $M$.

183 thermoautitrophicus was evaluated by measuring $\mathrm{CH}_{4}$ partial pressure using gas

184 chromatography.

S. oneidensis, the model organism most susceptible to $\mathrm{CO}_{2}$ exposure of those tested,

186 was selected for a second set of experiments that examined the effects of mineral solid phases

187 on $\mathrm{CO}_{2}$ toxicity (Santillan et al., 2013). Minerals and rock samples (Ward's Natural Science,

188 Rochester, NY) were crushed to the size of coarse sand, cleaned of any magnetite they may

189 have contained using a hand magnet, and sterilized at $121^{\circ} \mathrm{C}$ for $30 \mathrm{~min}$. Test tubes with $10 \mathrm{~mL}$

190 of growth medium and $1 \mathrm{~g}$ of autoclaved mineral were inoculated with S. oneidensis and 
191 anaerobically incubated at $30^{\circ} \mathrm{C}$ for 3 days. Test cultures were then exposed to $2.5 \mathrm{MPa}^{\mathrm{CO}_{2}}$ for

192 up to $8 \mathrm{~h}$. The impact of $\mathrm{CO}_{2}$ exposure on cell survival was assessed by comparing the culturable 193 cell content of test cultures to identical cultures that were not exposed to high-pressure $\mathrm{CO}_{2}$. In 194 both cases, the cultures were sonicated prior to culturing to disperse cells and cell survival was 195 evaluated using pour plating. Samples of minerals and cells were imaged using scanning 196 electron microscopy (SEM) following termination of the experiments.

197 For our pure-culture tests, control experiments were performed to assess the impact of 198 sonication and pressure changes on cell survival. Results indicate that neither factor 199 significantly impacted the culturable cell concentrations we measured. A set of control 200 experiments was also included to examine the extent to which biofilm protected cells during 201 exposure to high-pressure $\mathrm{CO}_{2}$. For those controls, the cultures were sonicated prior to $\mathrm{CO}_{2}$ 202 exposure to disperse biofilm cells.

\subsection{Bioclogging experiments}

Column experiments were performed to examine how sudden acidification of water

206 would impact the stability of biofilm in porous media (Kirk et al., 2012). The experiments were

207 run in $10 \mathrm{~cm}$ long square capillary tubes with a $1 \mathrm{~mm}^{2}$ cross-sectional area packed with $105-$

$208150 \mu \mathrm{m}$ diameter glass beads. Each experiment had three phases: pre-growth, growth at $\mathrm{pH}$

2097.2 , and acidic $\mathrm{pH}$, which started four days after inoculation. The acidic phases of six

210 biologically-active experiments received medium with an average $\mathrm{pH}$ of 4.0 and six additional

211 experiments received medium with an average $\mathrm{pH}$ of 5.7. Abiological-control experiments were 
212 also performed at $\mathrm{pH} 4$ (two) and $\mathrm{pH} 5.7$ (one). Experiments were terminated after hydraulic

213 conductivity was stable for at least $24 \mathrm{~h}$.

Artificial $\mathrm{Na}-\mathrm{Cl}$ type groundwater with glucose and bicarbonate was used as the aqueous

215 medium. Rhodamine, a fluorescent dye, was included for pore-space imaging. pH was adjusted

216 using $\mathrm{HCl}$. Medium was pumped through the columns at $0.015 \mathrm{~mL} \mathrm{~min}^{-1}$ (specific discharge of

$21722 \mathrm{~m} \mathrm{day}^{-1}$ ) using syringe pump. After the hydraulic properties were allowed to stabilize for at

218 least three days, the system was inoculated with an average of 8.4 log colony forming units

219 (CFU; stdev 0.3) of Pseudomonas fluorescens tagged with a green fluorescent protein (GFP).

220 Biofilm production by $P$. fluorescens is well characterized, including growth in flowing systems

221 (e.g., Pereira et al., 2002; Simoes et al., 2007; Simoes et al., 2005). A strain tagged with GFP was

222 chosen to allow biomass growth to be monitored nondestructively. Following inoculation, flow

223 was stopped for $2 \mathrm{~h}$ to allow initial cell attachment and growth to occur. Cells injected into the

224 control experiments were heat-sterilized before injection.

225 The average saturated hydraulic conductivity over the entire length of each column was

226 evaluated for each of the three phases of the experiments based on pressure measurements.

227 Pores and biomass were imaged with a scanning laser confocal microscope during the

228 experiments. Culturable cell concentrations in column effluent were measured periodically

229 throughout the experiment by plating effluent samples. For two pH 4 and three $\mathrm{pH} 5.7$

230 experiments, effluent cell abundance was also quantified using live-dead staining. This

231 approach provides a measure of cell viability that, unlike plating, is not influence by any

232 cultivation bias. After the experiments were terminated, the culturable cell content of $1 \mathrm{~cm}$

233 column segments was measured in one $\mathrm{pH} 4$ and one $\mathrm{pH} 5.7$ experiment. 
Experiments were carried out with bioreactors containing a mixed-microbial community

237 to examine how changes in $\mathrm{CO}_{2}$ abundance could alter interactions between groups of

238 microbes that naturally co-exist (Kirk et al., 2013). Unlike the pure-culture experiments, which

239 isolate factors that influence cell survival, these experiments consider how an increase in $\mathrm{CO}_{2}$

240 could affect interactions between different functional groups of microorganisms.

The experiments were carried out in duplicate using anoxic semi-continuous

242 bioreactors. Microbes and groundwater for the experiments were obtained from a freshwater

243 aquifer. Two sets of experiments were performed: one with low $\mathrm{CO}_{2}$ partial pressure ( 0.002

$244 \mathrm{MPa}$ ) in the headspace of the reactors and one with high $\mathrm{CO}_{2}$ partial pressure ( 0.1 $\left.\mathrm{MPa}\right)$.

245 Hereafter, we refer to these experiments as the low- $\mathrm{CO}_{2}$ bioreactors and high- $\mathrm{CO}_{2}$ bioreactors, 246 respectively. A fluid residence time of 35 days was maintained in the reactors by replacing one-

247 fifth of the aqueous volume with fresh medium every seven days. The aqueous medium was 248 composed of groundwater amended with small amounts of acetate $(250 \mu \mathrm{M})$, phosphate $(1$ $249 \mu \mathrm{M})$, and ammonium $(50 \mu \mathrm{M})$ to stimulate microbial activity. Synthetic goethite $(1 \mathrm{mmol})$ and 250 sulfate (500 $\mu \mathrm{M}$ influent concentration) were also available in each reactor to serve as electron 251 acceptors.

252 Reactors were incubated for 15 weeks. During that time, influent medium and reactor 253 effluent were regularly sampled and analyzed using a variety of techniques. The ferrozine 254 method was used to analyze ferrous iron concentration (Stookey, 1970). Ion chromatography 255 was used to analyze anion concentrations. Gran alkalinity titrations were used to evaluate 
256 alkalinity. Atomic adsorption and inductively coupled plasma optical emissions spectroscopy

257 were used to measure cation concentrations. Rates of acetate oxidation, iron reduction, and

258 sulfate reduction were directly evaluated using mass-balance calculations based on measured

259 reactor chemistry.

Well-mixed samples of reactor solids and fluid were collected at the end of the

261 incubations for analysis of reactor solid phases and microbial community composition. Total

262 community DNA was extracted from microbial samples using an Ultraclean ${ }^{\circledast}$ Microbial DNA

263 Isolation Kit (MO BIO) and then sequenced using 454 pyrosequencing. Sequences were then

264 processed using QIIME (Caporaso et al., 2010). During processing, the software used

265 AmpliconNoise to remove sequencing errors (Quince et al., 2011).

266

267

2.5. Numerical analysis

268

Bioenergetics calculations were used to consider how increasing $\mathrm{CO}_{2}$ abundance affects

269 redox disequilibrium and, in turn, microbial activity. Calculations were performed using data

270 collected during two field $\mathrm{CO}_{2}$-injection experiments (Kirk, 2011) and with data collected from

271 the mixed-community experiments (Kirk et al., 2013). In both cases, the calculations assessed

272 changes in energy available $\left(\Delta G_{A}\right)$ for microbial metabolism. As defined previously (Bethke et

273 al., 2011), $\Delta G_{A}$ is the negative of the free energy change of microbial metabolic reaction $\left(\Delta G_{r}\right)$

274 and can be calculated in units of $\mathrm{kJ} \cdot \mathrm{mol}^{-1}$ as follows:

$$
\Delta G_{A}=-\Delta G_{r}=-\left[\Delta G_{T}^{\circ}+R T \ln \prod_{i}\left(\gamma_{i} \times m_{i}\right)^{v_{i}}\right]
$$

275 where $\Delta G_{T}^{\circ}$ is the standard Gibbs free-energy change for reaction $r$ at temperature $T\left({ }^{\circ} \mathrm{K}\right), R$

276 represents the gas constant $\left(\mathrm{kJ} \cdot \mathrm{mol}^{-1} \cdot \mathrm{K}^{-1}\right), \gamma_{i}$ and $m_{i}$ are the activity coefficient (molal ${ }^{-1}$ ) and 
277 molality of the $i$ th chemical species in the reaction, and $v_{i}$ is the stoichiometric coefficient of 278 that species, which is positive for products and negative for reactants.

280 Geochemists Workbench ${ }^{\circledR}$ software package (Bethke, 2009) and the Lawrence Livermore 281 National Laboratory thermodynamic database (Delany and Lundeen, 1990). Activities were 282 calculated from chemical data with Geochemists Workbench ${ }^{\circledR}$ software using an extended form 283 of the Debye-Hückel equation, the $B$-dot equation (Helgeson, 1969).

Calculations for the mixed-community experiments considered iron reduction and sulfate reduction, the two groups of microorganisms that account for all of the microbial 286 activity during the experiments. Calculations for the field studies considered iron reduction, 287 sulfate reduction, and methanogenesis. Those groups were selected because they are the three most common groups of respiring microorganisms in the subsurface (Bethke et al., 2011; Lovley 289 and Chapelle, 1995; McMahon and Chapelle, 2008). As such, they are likely present in many 290 potential storage reservoirs that contain active microbial populations. experiment and the Zero Emissions Research and Technology (ZERT) experiment (Kharaka et al.,

293 2006; Kharaka et al., 2010). To account for errors associated with activity modeling and 294 uncertainty regarding electron donor concentrations, results from the bioenergetics analysis of 295 the field data are normalized relative to conditions present prior to $\mathrm{CO}_{2}$ injection, as follows:

$$
\Delta G_{A}^{\mathrm{CO}_{2}}-\Delta G_{A}^{\text {initial }}=\Delta G_{A}^{n}
$$

297 where the superscript " $\mathrm{CO}_{2}$ " designates each value calculated during or after $\mathrm{CO}_{2}$ injection 298 began, "initial" designates the value calculated prior to injection, and " $\mathrm{n}$ " represents the 
normalized value. As such, our analysis of the field data considered how energy available changed as a result of $\mathrm{CO}_{2}$ injection, not absolute values of energy available.

\section{Results and discussion}

The integration of our studies yields insight into the interplay between subsurface microbes and GCS beyond that possible within each individual study. In the subsections that follow, we examine the results of our studies within the context of these two-way interactions.

\subsection{Impacts of GCS on microbiology}

\subsubsection{Factors influencing cell survival}

Results of our isolation and pure-culture experiments indicate that cells that have properties that limit $\mathrm{CO}_{2}$ accumulation in their cytoplasm are better able to survive exposure to high pressure $\mathrm{CO}_{2}$. These properties include the make-up of their cell wall and membranes, the nature of their metabolic reactions, and whether they exist within biofilm.

We found that isolate CG-1 exhibits a fermentative metabolism and was most related (98.5\%) to Lactobacillus casei (Santillan et al., 2015). It grows at $\mathrm{CO}_{2}$ partial pressures between

0 and $1.0 \mathrm{MPa}$ and is able to survive for at least 5 days at $2.5 \mathrm{MPa} \mathrm{CO}$ and for at least 1 day at 5 $\mathrm{MPa} \mathrm{CO}$. CG-1 morphology and fatty acid composition both vary with $\mathrm{CO}_{2}$ partial pressure. Images collected from cultures with $0.1 \mathrm{MPa} \mathrm{CO}_{2}$ show rod-shaped cells. In images collected from cultures with $1 \mathrm{MPa} \mathrm{CO}$, however, cells are generally smaller and encased in capsular material (Figure 1). With increasing $\mathrm{CO}_{2}$ partial pressure, monounsaturated fatty acids decreased in relative abundance while saturated fatty acids increased. Production of capsular 
321 material and the changes in lipid composition at high $\mathrm{CO}_{2}$ levels are consistent with a decrease

322 in the flexibility and perhaps permeability of the cells.

Strains tested in our pure-culture experiments varied in their ability to survive exposure

324 to high-pressure $\mathrm{CO}_{2}$ (Santillan et al., 2013). For all organisms, survival was best at low $\mathrm{CO}_{2}$

325 pressures but decreased as pressures increased. S. oneidensis cells were the most sensitive to

326 increased $\mathrm{CO}_{2}$ while $\mathrm{G}$. stearothermophilus cells were the most resilient. because they possess Gram positive cell walls as well as the capacity to form endospores. Cell wall and membrane composition influence the extent to which $\mathrm{CO}_{2}$ can penetrate cells

330 (Bertoloni et al., 2006; Zhang et al., 2006). Gram positive cell walls are more rigid and less

331 permeable than Gram negative cell walls. Sporulation can provide a mechanism by which cells 332 can reduce themselves into a more durable form until $\mathrm{CO}_{2}$ stress is removed (Furukawa et al., 333 2004; Watanabe et al., 2003). Differences in survival between $M$. thermoautitrophicus and S. oneidensis cells may also 335 reflect differences in the ability of $\mathrm{CO}_{2}$ to penetrate the cells. Archaea, such as $M$. 336 thermoautitrophicus, possess cell membranes that differ considerably from those of Bacteria.

337 Because of those differences, they are thought to generally be better able to withstand 338 extreme conditions (Arakawa et al., 1999; Gambacorta et al., 1994). In addition, differences in 339 metabolism between the strains may have also contributed to variation in cell survival. Unlike $S$. 340 oneidensis, $M$. thermoautitrophicus cells consume $\mathrm{CO}_{2}$ in their catabolic reaction, potentially 341 helping them limit accumulation of $\mathrm{CO}_{2}$ within their cytoplasm. The isolation process of CG-1 342 suggests it may similarly benefit from intracellular $\mathrm{CO}_{2}$ consumption. Many fermenters utilize 
$343 \mathrm{CO}_{2}$ in metabolic processes, such as amino acid synthesis or through $\mathrm{C}_{1}$ metabolism (Arioli et al., 344 2009; Bringel et al., 2008; Song et al., 2007).

Results from our experiments that included minerals, indicate that the mere presence of

346 a mineral can enhance the ability of S. oneidensis cells to survive exposure to high pressure $\mathrm{CO}_{2}$

347 (Santillan et al., 2013). With the exception of kaolinite, cell survival was higher in cultures

348 containing minerals than those without (Figure 2). We hypothesize that these results reflect the 349 shelter provided by biofilm. Unlike planktonic cells, biofilm cells are surrounded by extracellular 350 polymeric substances (EPS), which limits their exposure to environmental stresses such as high351 pressure $\mathrm{CO}_{2}$ (Mitchell et al., 2008; Mitchell et al., 2009). Surface area available for biofilm 352 formation was greater in cultures that contained minerals than those that did not. SEM images 353 (not shown) confirm that biofilm formation did occur on mineral surfaces during the 354 experiment.

\subsubsection{Persistence of attached biomass}

358 following sudden acidification of water, even if considerable cell death occurs (Kirk et al., 2012).

359 After 4 days of growth at $\mathrm{pH} 7.2$, a 0.67 log reduction in the overall hydraulic conductivity of the columns occurred, on average (Figure 3). Acidification caused hydraulic conductivity to increase

361 significantly in all but one pH 5.7 experiment as well as extensive cell death and stress,

362 particularly in $\mathrm{pH} 4$ experiments. However, the columns remained significantly clogged relative

363 to pre-growth conditions. Following acidification, log reductions in hydraulic conductivity

364 averaged 0.43 and $0.65 \mathrm{in} \mathrm{pH} 4$ and $\mathrm{pH} 5.7$ experiments, respectively. 


\subsubsection{Shifts in microbial reactions}

Our mixed-community experiments and numerical analyses show that increasing $\mathrm{CO}_{2}$ concentration favors microbial reactions that consume acid. As a result, microbial communities that emerge following injection of $\mathrm{CO}_{2}$ may differ from indigenous communities not only because they are better at tolerating $\mathrm{CO}_{2}$ stress but also because the balance between different 371 microbial reactions has shifted.

Microbial activity differed considerably between the high- and low- $\mathrm{CO}_{2}$ bioreactors in

373 our mixed-community experiments (Kirk et al., 2013). Mass-balance calculations demonstrate 374 that sulfate reduction was dominant in reactors with low $\mathrm{CO}_{2}$ content. The reaction consumed $37585 \%$ of the acetate after acetate consumption reached steady state while iron reduction 376 accounted for only $15 \%$ on average (Figure 4). In contrast, iron reduction was dominant during 377 that same interval in reactors with high $\mathrm{CO}_{2}$ content, accounting for at least $90 \%$ of the acetate 378 consumption while sulfate reduction consumed a negligible amount $(<1 \%)$.

380 (Kirk et al., 2013). Sequences classified in groups that contain species related to iron reduction 381 were abundant in samples from all biologically-active reactors but more than twice as abundant 382 in the high- $\mathrm{CO}_{2}$ reactor samples compared to the low- $\mathrm{CO}_{2}$ reactor samples. Moreover, 383 sequences classified in groups relating to sulfate reducers were abundant in the low- $\mathrm{CO}_{2}$ 384 reactor samples but nearly absent from the high- $\mathrm{CO}_{2}$ reactor samples.

Bioenergetics calculations show that the rate of microbial iron reduction may have 
387 was much more energetically favorable in reactors that hosted more rapid iron reduction, the 388 high- $\mathrm{CO}_{2}$ reactors, than those with slower iron reduction rates, the low- $\mathrm{CO}_{2}$ reactors. After 389 acetate consumption stabilized, energy available for microbial iron reduction was $114 \mathrm{~kJ} \mathrm{~mol}^{-1}$ 390 and $60 \mathrm{~kJ} \mathrm{~mol}^{-1}$, on average in the high- and low-CO2 bioreactors, respectively. In contrast, thermodynamic controls on microbial sulfate reduction could not be 392 responsible for variation in the rate of that reaction. Energy available for sulfate reduction 393 varied little, averaging a maximum of $65 \mathrm{~kJ} \mathrm{~mol}^{-1}$ and $62 \mathrm{~kJ} \mathrm{~mol}^{-1}$ in the high- and low- $\mathrm{CO}_{2}$ 394 reactors, respectively. Instead, we hypothesize that the rate of sulfate reduction varied in 395 response to competition for electron donor from iron reduction (Kirk et al., 2013). Where 396 energy available for microbial iron reduction was high, the reaction occurred rapidly and little 397 electron donor remained for sulfate reduction. However, where energy available for iron 398 reduction was low, the reaction slowed, allowing sulfate reduction to consume excess electron 399 donor.

Bioenergetic calculations performed using data from the field $\mathrm{CO}_{2}$-injection experiments

401 provide results that parallel those from the mixed-community experiments. $\mathrm{CO}_{2}$ injection 402 benefitted iron reduction much more than sulfate reduction or methanogenesis at both field 403 sites (Kirk, 2011). For both acetotrophic and hydrogentrophic reactions, the energy available for 404 iron reduction increased considerably for all three iron minerals considered as electron 405 acceptors in iron-reduction reactions (Figure 5). In contrast, energy available for sulfate 406 reduction and methanogenesis varied relatively little. In both sets of calculations, the energy advantage gained by iron reduction with 408 increased $\mathrm{CO}_{2}$ levels primarily reflects changes in $\mathrm{pH}$. Reduction of ferric iron in oxides and 

424 tested.

425 $\mathrm{pH}$.

oxyhydroxides consumes a large number of protons. As such, the energy yield of iron reduction increases sharply as $\mathrm{pH}$ decreases. Sulfate reduction and methanogenesis, however, consume relatively few protons. As such, the energy yield of those reactions does not vary strongly with

Our numerical and mixed-culture studies indicate that $\mathrm{CO}_{2}$ injection has the potential to stimulate microbial iron reduction where ferric iron is available. At first glance, these results seem to be in conflict with our isolate experiments. In those experiments, S. oneidensis, an organism capable of dissimilatory iron reduction, showed greater sensitivity to elevated $\mathrm{CO}_{2}$ than M. thermoautitrophicus, a methanogen. However, individual isolates are not representative of an entire metabolic group of microorganisms. Cells capable of dissimilatory iron reduction, for example, have broad phylogenetic diversity and have been identified across a wide range of chemical and physical conditions, including at extreme acidic $\mathrm{pH}$ and salinity (Emmerich et al., 2012; Itoh et al., 2011; Lu et al., 2010; Weber et al., 2006). The mixedcommunity of iron-reducing microorganisms that may exist in a GCS reservoir, therefore, may be better able to adapt to an increase in the abundance of $\mathrm{CO}_{2}$ than the individual isolate we

\subsection{Impacts of microbiology on GCS}

\subsubsection{Impacts of microbiology on flow}

Similar to our findings, previous studies have shown that biofilm can remain largely intact in porous media during exposure to supercritical $\mathrm{CO}_{2}$ (Mitchell et al., 2008; Mitchell et al., 2009). Combined with our efforts, the results of these studies provide compelling evidence that 
431 hydraulic conductivity will change little in response to biofilm redistribution following injection

432 of $\mathrm{CO}_{2}$ into GCS reservoirs where biofilms are present. If microbial biomass influences hydraulic 433 conductivity before $\mathrm{CO}_{2}$ is injection into a $\mathrm{GCS}$, our results and those of previous studies suggest

434 it will influence hydraulic conductivity afterward as well.

These findings imply that, in biologically activity GCS reservoirs, microbial biofilms can

436 influence the flow of $\mathrm{CO}_{2}$ and water away from injection wells. Consistent with this implication,

437 previous studies found that microbial activity significantly decreased the injectivity of a $\mathrm{CO}_{2}^{-}$

438 injection well at the Ketzin site (Morozova et al., 2010; Zettlitzer et al., 2010). In addition,

439 biofilm on a mineral surface may alter the wettability of those minerals, which is a major

440 control on residual trapping of $\mathrm{CO}_{2}$ (Chaudhary et al., 2013).

441

442

\subsubsection{Impacts of microbiology on solution and mineral trapping}

Results of the mixed-community experiments show that, where $\mathrm{CO}_{2}$ injection stimulates

444 microbial iron reduction, solubility trapping may be enhanced. Because microbial reduction of

445 ferric iron in iron oxides and oxyhydroxides consumes a large number of protons, the reaction

446 works to convert $\mathrm{CO}_{2}$ into carbonate alkalinity, thereby enhancing storage of inorganic carbon

447 in solution (Kirk et al., 2013). Reflecting this relationship, the increase in carbonate alkalinity

448 caused by microbial activity in high- $\mathrm{CO}_{2}$ bioreactors was six-fold greater than that in the low-

$449 \mathrm{CO}_{2}$ bioreactors (Figure 6). Mitchell et al. (2010) describe a similar effect during bacterial

450 hydrolysis of urea batch reactor experiments containing elevated $\mathrm{CO}_{2}$ content. The results of

451 these studies suggest that we may need to consider the response of the microbial community

452 to $\mathrm{CO}_{2}$ injection in order to accurately predict rates of solution trapping in GCS reservoirs. 
In addition to solution trapping, microbial activity also has the potential to impact

454 mineral trapping. Alkalinity generation by acid-consuming microorganisms works to increase 455 the saturation state of carbonate minerals such as calcite $\left(\mathrm{CaCO}_{3}\right)$ and siderite $\left(\mathrm{FeCO}_{3}\right)($ Kirk et

456 al., 2013; Mitchell et al., 2010). Moreover, cells and biofilms can also facilitate carbonate

457 mineralization by providing nucleation cites (Benzerara et al., 2011; Mitchell and Ferris, 2006).

458 Hence, rates of mineral trapping may also be influenced by the response of the microbial 459 community to $\mathrm{CO}_{2}$ injection.

460

461

\subsection{Future research}

Our efforts and those of many other researchers have to date been weighted toward

463 understanding one side of the interplay between microbiology and GCS: the impact of GCS on

464 microbial activity. This area of research is important. We can understand how microbes will

465 affect GCS without knowing what physical and functional characteristics GCS reservoirs will

466 select for. However, we suggest that more attention needs to be paid to the impact of

467 microbiology on GCS.

Many questions about this component of GCS geomicrobiology remain unresolved.

469 Little is known about the nature of microbial impacts on GCS and their relative significance. For

470 example, how will alkalinity production by acid-consuming microorganisms compare to that

471 generated by abiological reactions between $\mathrm{CO}_{2}$ and minerals? We also do not have a clear

472 basis for identifying which GCS reservoirs are more likely to host significant microbial impacts.

473 Should our attention focus on organic-rich reservoirs (e.g., depleted oil reservoirs and coalbeds)

474 or will microbial reaction rates be significant relative to the time scale of GCS in all reservoirs? 
475 Answering these questions will constrain the extent to which numerical models need to include 476 microbial activity to accurately simulate the long-term fate of $\mathrm{CO}_{2}$ in the subsurface.

Future laboratory research needs to simulate conditions consistent with GCS reservoirs.

478 GCS reservoirs will commonly be anoxic, with heterogeneous mineralogy and microbiology and 479 elevated pressure, temperature, and salinity. Many recent laboratory studies were performed 480 under relevant conditions (e.g., Dupraz et al., 2013; Mayumi et al., 2013; Ohtomo et al., 2013;

481 Peet et al., 2015; Wilkins et al., 2014). However, most of what we know about the impact of 482 high pressure $\mathrm{CO}_{2}$ on microbiology stems from food industry research into $\mathrm{CO}_{2}$ as a sterilizing 483 agent (e.g., Amanatidou et al., 1999; Spilimbergo et al., 2002; Watanabe et al., 2003; Zhang et 484 al., 2006). Follow-up experiments are warranted to test some of the research questions in those 485 studies under conditions consistent with GCS reservoirs.

487 that could create an energy return on subsurface $\mathrm{CO}_{2}$ injection. For example, recent research 488 has found evidence that $\mathrm{CO}_{2}$ injection can stimulate biological conversion of crude oil into 489 natural gas (Mayumi et al., 2013). $\mathrm{CO}_{2}$ injection into depleted or heavy oil reservoirs, therefore, 490 may provide a strategy to enhance energy recovery from those systems and alleviate some of 491 the economic burden of GCS.

\section{Conclusions}

Geomicrobiology studies performed by CFSES examine impacts of GCS on subsurface 495 microbiology. Pure-culture and isolation studies identify factors that may influence survival, 496 including environmental, biochemical, and structural characteristics. Our column experiments 
497 show that biofilm can remain largely intact following sudden acidification of water, even if

498 significant cell death and stress occurs. Mixed-community experiments and thermodynamic

499 calculations show that the balance between microbial reactions can shift in response to

500 changes in fluid chemistry caused by increasing $\mathrm{CO}_{2}$ levels. Collectively, these efforts add to the

501 growing body of evidence that microbial life will persist in GCS reservoirs, likely defined by

502 communities that differ from those present prior to injection. Our work suggests that

503 communities will change in response to differences in the ability of cells to tolerate elevated

$504 \mathrm{CO}_{2}$ levels as well as shifts in the balance of microbial reactions.

505 These studies also shed light on potential impacts of subsurface microbial communities

506 on GCS. Subsurface biomass may influence the hydrodynamics of porous media in GCS

507 reservoirs, affecting flow away from injection wells and capillary trapping of $\mathrm{CO}_{2}$. Coupled with

508 this effect, by catalyzing oxidation-reduction reactions, microorganisms can affect the rate and

509 form of solubility and mineral trapping. The potential importance of microbial activity in GCS

510 reservoirs, therefore, should not be overlooked.

512 Acknowledgements

513 This material is based upon work supported as part of the Center for Frontiers of

514 Subsurface Energy Security, an Energy Frontier Research Center funded by the U.S. Department

515 of Energy, Office of Science, Office of Basic Energy Sciences under Award Number DE-

516 SC0001114. Sandia National Laboratories is a multi-program laboratory managed and operated

517 by Sandia Corporation, a wholly owned subsidiary of Lockheed Martin Corporation, for the U.S.

518 Department of Energy's National Nuclear Security Administration under contract DE-AC04- 
94AL85000. Matthew Kirk conducted the laboratory and modeling work presented in this paper

while at Sandia National Laboratories.

\section{References}

Amanatidou, A., Smid, E. J., and Gorris, L. G. M. (1999). Effect of elevated oxygen and carbon dioxide on the surface growth of vegetable-associated micro-organisms. Journal of Applied Microbiology 86, 429-438. 10.1046/j.1365-2672.1999.00682.x

Arakawa, K., Kano, H., Eguchi, T., Nishiyama, Y., and Kakinuma, K. (1999). Significance of the 72membered macrocyclic structure found in archaeal membrane lipids: Model studies of the macrocyclic tetraether diphospholipids by calorimetric, P-31 NMR, and electron microscopic analyses. Bulletin of the Chemical Society of Japan 72, 1575-1581. 10.1246/bcsj.72.1575

Arioli, S., Roncada, P., Salzano, A. M., Deriu, F., Corona, S., Guglielmetti, S., Bonizzi, L., Scaloni, A., and Mora, D. (2009). The relevance of carbon dioxide metabolism in Streptococcus thermophilus. Microbiology-SGM 155, 1953-1965. 10.1099/mic.0.024737-0

Baker, B. J., Comolli, L. R., Dick, G. J., Hauser, L. J., Hyatt, D., Dill, B. D., Land, M. L., VerBerkmoes, N. C., Hettich, R. L., and Banfield, J. F. (2010). Enigmatic, ultrasmall, uncultivated Archaea. Proceedings of the National Academy of Sciences 107, 8806-8811. 10.1073/pnas.0914470107

Ballestra, P., Dasilva, A. A., and Cuq, J. L. (1996). Inactivation of Escherichia coli by carbon dioxide under pressure. Journal of Food Science 61, 829-\&. 10.1111/j.1365-2621.1996.tb12212.x

Banks, E. D., Taylor, N. M., Gulley, J., Lubbers, B. R., Giarrizo, J. G., Bullen, H. A., Hoehler, T. M., and Barton, H. A. (2010). Bacterial calcium carbonate precipitation in cave environments: A function of calcium homeostasis. Geomicrobiology Journal 27, 444-454. 10.1080/01490450903485136

Baveye, P., Vandevivere, P., Hoyle, B. L., DeLeo, P. C., and de Lozada, D. S. (1998). Environmental impact and mechanisms of the biological clogging of saturated soils and aquifer materials. Critical Reviews in Environmental Science and Technology 28, 123-191. 10.1080/10643389891254197

Benson, S. M., Cook, P., Anderson, J., Bachu, S., Hassan, B. N., Basu, B., Bradshaw, J., Deguchi, G., Gale, J., von Goerne, G., Heidug, W., Holloway, S., Kamal, R., Keith, D., Lloyd, P., Rocha, P., Senior, B., Thomson, J., Torp, T., Wildenborg, T., Wilson, M., Zarlenga, F., Zhou, D., Celia, M., Gunter, B., King, J. E., Lindeberg, E., Lombardi, S., Oldenburg, C., Pruess, K., Rigg, A., Stevens, S., Wilson, E., and Whittaker, S. (2005). Underground geological storage, in Metz, B., Davidson, O., de Coninck, H., Loos, M., and Meyer, L., eds., Carbon Dioxide Capture and Storage: Cambridge, England, Cambridge University Press, p. 431.

Benzerara, K., Miot, J., Morin, G., Ona-Nguema, G., Skouri-Panet, F., and Ferard, C. (2011). Significance, mechanisms and environmental implications of microbial biomineralization. Comptes Rendus Geoscience 343, 160-167. 10.1016/j.crte.2010.09.002

Bertoloni, G., Bertucco, A., De Cian, V., and Parton, T. (2006). A study on the inactivation of microorganisms and enzymes by high pressure $\mathrm{CO}_{2}$. Biotechnology and Bioengineering 95, 155-160. 10.1002/bit.21006

Bethke, C. M. (2009). The Geochemist's Workbench: Champaign, IL, Aqueous Solutions, LLC.

Bethke, C. M., Sanford, R. A., Kirk, M. F., Jin, Q., and Flynn, T. M. (2011). The thermodynamic ladder in geomicrobiology. American Journal of Science 311, 183-210. 10.2475/03.2011.01

Bringel, F., Hammann, P., Kugler, V., and Arsene-Ploetze, F. (2008). Lactobacillus plantarum response to inorganic carbon concentrations: PyrR(2)-dependent and -independent transcription regulation 
of genes involved in arginine and nucleotide metabolism. Microbiology-SGM 154, 2629-2640. 10.1099/mic.0.2008/018184-0

Burnside, N. M., Shipton, Z. K., Dockrill, B., and Ellam, R. M. (2013). Man-made versus natural $\mathrm{CO}_{2}$ leakage: A 400 k.y. history of an analogue for engineered geological storage of $\mathrm{CO}_{2}$. Geology 41, 471-474. 10.1130/g33738.1

Caporaso, J. G., Kuczynski, J., Stombaugh, J., Bittinger, K., Bushman, F. D., Costello, E. K., Fierer, N., Pena, A. G., Goodrich, J. K., Gordon, J. I., Huttley, G. A., Kelley, S. T., Knights, D., Koenig, J. E., Ley, R. E., Lozupone, C. A., McDonald, D., Muegge, B. D., Pirrung, M., Reeder, J., Sevinsky, J. R., Tumbaugh, P. J., Walters, W. A., Widmann, J., Yatsunenko, T., Zaneveld, J., and Knight, R. (2010). QIIME allows analysis of high-throughput community sequencing data. Nature Methods 7, 335-336. 10.1038/nmeth.f.303

Chaudhary, K., Cardenas, M. B., Wolfe, W. W., Maisano, J. A., Ketcham, R. A., and Bennett, P. C. (2013). Pore-scale trapping of supercritical $\mathrm{CO}_{2}$ and the role of grain wettability and shape. Geophysical Research Letters 40, 3878-3882. 10.1002/grl.50658

Chenna, R., Sugawara, H., Koike, T., Lopez, R., Gibson, T. J., Higgins, D. G., and Thompson, J. D. (2003). Multiple sequence alignment with the Clustal series of programs. Nucleic Acids Research 31, 3497-3500. 10.1093/nar/gkg500

Colwell, F. S., and D'Hondt, S. (2013). Nature and Extent of the Deep Biosphere, in Hazen, R. M., Jones, A. P., and Baross, J. A., eds., Carbon in Earth, Volume 75, p. 547-574. 10.2138/rmg.2013.75.17

Cunningham, A. B., Gerlach, R., Spangler, L., and Mitchell, A. C. (2009). Microbially Enhanced Geologic Containment of Sequestered Supercritical $\mathrm{CO}_{2}$, in Gale, J., Herzog, H., and Braitsch, J., eds., Greenhouse Gas Control Technologies 9, Volume 1, p. 3245-3252. 10.1016/j.egypro.2009.02.109

Davidson, M. M., Silver, B. J., Onstott, T. C., Moser, D. P., Gihring, T. M., Pratt, L. M., Boice, E. A., Lollar, B. S., Lippmann-Pipke, J., Pfiffner, S. M., Kieft, T. L., Seymore, W., and Ralston, C. (2011). Capture of Planktonic Microbial Diversity in Fractures by Long-Term Monitoring of Flowing Boreholes, Evander Basin, South Africa. Geomicrobiology Journal 28, 275-300. 10.1080/01490451.2010.499928

Delany, J. M., and Lundeen, S. R. (1990). The LLNL thermochemical database: Lawrence Livermore National Laboratory, LLNL report UCRL-21658.

Dillow, A. K., Dehghani, F., Hrkach, J. S., Foster, N. R., and Langer, R. (1999). Bacterial inactivation by using near- and supercritical carbon dioxide. Proceedings of the National Academy of Sciences of the United States of America 96, 10344-10348. 10.1073/pnas.96.18.10344

Dupraz, S., Fabbri, A., Joulian, C., Dictor, M. C., Battaglia-Brunet, F., Menez, B., Crouzet, C., Henry, B., and Garrido, F. (2013). Impact of $\mathrm{CO}_{2}$ concentration on autotrophic metabolisms and carbon fate in saline aquifers - A case study. Geochimica et Cosmochimica Acta 119, 61-76. 10.1016/j.gca.2013.05.027

Emerson, J. B., Thomas, B. C., Alvarez, W., and Banfield, J. F. (2015). Metagenomic analysis of a high carbon dioxide subsurface microbial community populated by chemolithoautotrophs and bacteria and archaea from candidate phyla. Environmental Microbiology. 10.1111/14622920.12817

Emmerich, M., Bhansali, A., Loesekann-Behrens, T., Schroeder, C., Kappler, A., and Behrens, S. (2012). Abundance, Distribution, and Activity of Fe(II)-Oxidizing and Fe(III)-Reducing Microorganisms in Hypersaline Sediments of Lake Kasin, Southern Russia. Applied and Environmental Microbiology 78, 4386-4399. 10.1128/aem.07637-11

Flynn, T. M., Sanford, R. A., Ryu, H., Bethke, C. M., Levine, A. D., Ashbolt, N. J., and Domingo, J. W. S. (2013). Functional microbial diversity explains groundwater chemistry in a pristine aquifer. BmC Microbiology 13. 10.1186/1471-2180-13-146 
Fredrickson, J. K., Zachara, J. M., Kennedy, D. W., Dong, H., Onstott, T. C., Hinman, N. W., and Li, S.-m. (1998). Biogenic iron mineralization accompanying the dissimilatory reduction of hydrous ferric oxide by a groundwater bacterium. Geochimica et Cosmochimica Acta 62, 3239-3257. 10.1016/S0016-7037(98)00243-9

Furukawa, S., Watanabe, T., Tai, T., Hirata, J., Narisawa, N., Kawarai, T., Ogihara, H., and Yamasaki, M. (2004). Effect of high pressure gaseous carbon dioxide on the germination of bacterial spores. International Journal of Food Microbiology 91, 209-213. 10.1016/0168-1605(03)00372-6

Gambacorta, A., Trincone, A., Nicolaus, B., Lama, L., and Derosa, M. (1994). Unique features of lipids of archaea. Systematic and Applied Microbiology 16, 518-527.

Gorbushina, A. A. (2007). Life on the rocks. Environmental Microbiology 9, 1613-1631. 10.1111/j.14622920.2007.01301.x

Harvey, O. R., Qafoku, N. P., Cantrell, K. J., Lee, G., Amonette, J. E., and Brown, C. F. (2013). Geochemical implications of gas leakage associated with geological $\mathrm{CO}_{2}$ storage - a qualitative review. Environmental Science \& Technology 47, 23-36.

Helgeson, H. C. (1969). Thermodynamics of hydrothermal systems at elevated temperatures and pressures. American Journal of Science 267, 729-804.

Itoh, T., Yamanoi, K., Kudo, T., Ohkuma, M., and Takashina, T. (2011). Aciditerrimonas ferrireducens gen. nov., sp nov., an iron-reducing thermoacidophilic actinobacterium isolated from a solfataric field. International Journal of Systematic and Evolutionary Microbiology 61, 1281-1285. 10.1099/ijs.0.023044-0

Jin, Q. (2012). Energy conservation of anaerobic respiration. American Journal of Science 312, 573-628. 10.2475/06.2012.01

Kandianis, M. T., Fouke, B. W., Johnson, R. W., Veysey, J., II, and Inskeep, W. P. (2008). Microbial biomass: A catalyst for $\mathrm{CaCO}_{3}$ precipitation in advection-dominated transport regimes. Geological Society of America Bulletin 120, 442-450. 10.1130/b26188.1

Kaszuba, J. P., and Janecky, D. R. (2009). Geochemical Impacts of Sequestering Carbon Dioxide in Brine Formations, in Carbon Sequestration and Its Role in the Global Carbon Cycle, in Mcpherson, B. J., and Sundquist, E. T., eds., Carbon Sequestration and Its Role in the Global Carbon Cycle: Washington, D. C., American Geophysical Union. 10.1029/2006GM000353

Kawaguchi, H., Sakuma, T., Nakata, Y., Kobayashi, H., Endo, K., and Sato, K. (2010). Methane production by Methanothermobacter thermautotrophicus to recover energy from carbon dioxide sequestered in geological reservoirs. Journal of Bioscience and Bioengineering 110, 106-108. 10.1016/j.jbiosc.2010.01.008

Kharaka, Y. K., Cole, D. R., Hovorka, S. D., Gunter, W. D., Knauss, K. G., and Freifeld, B. M. (2006). Gaswater-rock interactions in Frio Formation following $\mathrm{CO}_{2}$ injection: Implications for the storage of greenhouse gases in sedimentary basins. Geology 34, 577-580. 10.1130/g22357.1

Kharaka, Y. K., Thordsen, J. J., Kakouros, E., Ambats, G., Herkelrath, W. N., Beers, S. R., Birkholzer, J. T., Apps, J. A., Spycher, N. F., Zheng, L. E., Trautz, R. C., Rauch, H. W., and Gullickson, K. S. (2010). Changes in the chemistry of shallow groundwater related to the 2008 injection of $\mathrm{CO}_{2}$ at the ZERT field site, Bozeman, Montana. Environmental Earth Sciences 60, 273-284. 10.1007/s12665009-0401-1

Kieft, T. L., McCuddy, S. M., Onstott, T. C., Davidson, M., Lin, L. H., Mislowack, B., Pratt, L., Boice, E., Lollar, B. S., Lippmann-Pipke, J., Pfiffner, S. M., Phelps, T. J., Gihring, T., Moser, D., and van Heerden, A. (2005). Geochemically generated, energy-rich substrates and indigenous microorganisms in deep, ancient groundwater. Geomicrobiology Journal 22, 325-335. $10.1080 / 01490450500184876$ 
Kirk, M. F. (2011). Variation in energy available to populations of subsurface anaerobes in response to geological carbon storage. Environmental Science \& Technology 45, 6676-6682. 10.1021/es201279e

Kirk, M. F., Jin, Q., and Haller, B. R. (2015). Broad-scale evidence that pH influences the balance between microbial iron and sulfate reduction. Groundwater. 10.1111/gwat.12364

Kirk, M. F., Santillan, E. F. U., McGrath, L. K., and Altman, S. J. (2012). Variation in hydraulic conductivity with decreasing $\mathrm{pH}$ in a biologically-clogged porous medium. International Journal of Greenhouse Gas Control 11, 133-140. 10.1016/j.ijggc.2012.08.003

Kirk, M. F., Santillan, E. F. U., Sanford, R. A., and Altman, S. J. (2013). $\mathrm{CO}_{2}$-induced shift in microbial activity affects carbon trapping and water quality in anoxic bioreactors. Geochimica et Cosmochimica Acta 122, 198-208. 10.1016/j.gca.2013.08.018

LaRowe, D. E., and Amend, J. P. (2015). Catabolic rates, population sizes and doubling/replacement times of microorganisms in natural settings. American Journal of Science 315, 167-203. 10.2475/03.2015.01

Lovley, D. R., and Chapelle, F. H. (1995). Deep subsurface microbial processes. Reviews of Geophysics 33, 365-381.

Lovley, D. R., and Goodwin, S. (1988). Hydrogen concentrations as an indicator of the predominant terminal electron-accepting reactions in aquatic sediments. Geochimica et Cosmochimica Acta 52, 2993-3003. 10.1016/0016-7037(88)90163-9

Lu, S., Gischkat, S., Reiche, M., Akob, D. M., Hallberg, K. B., and Kuesel, K. (2010). Ecophysiology of FeCycling Bacteria in Acidic Sediments. Applied and Environmental Microbiology 76, 8174-8183. 10.1128/aem.01931-10

Mayumi, D., Dolfing, J., Sakata, S., Maeda, H., Miyagawa, Y., Ikarashi, M., Tamaki, H., Takeuchi, M., Nakatsu, C. H., and Kamagata, Y. (2013). Carbon dioxide concentration dictates alternative methanogenic pathways in oil reservoirs. Nature Communications 4. 10.1038/ncomms2998

McMahon, P. B., and Chapelle, F. H. (2008). Redox processes and water quality of selected principal aquifer systems. Ground Water 46, 259-271. 10.1111/j.1745-6584.2007.00385.x

Mitchell, A. C., Dideriksen, K., Spangler, L. H., Cunningham, A. B., and Gerlach, R. (2010). Microbially enhanced carbon capture and storage by mineral-trapping and solubility-trapping. Environmental Science \& Technology 44, 5270-5276. 10.1021/es903270w

Mitchell, A. C., and Ferris, F. G. (2006). The Influence of Bacillus pasteurii on the nucleation and growth of calcium carbonate. Geomicrobiology Journal 23, 213-226. 10.1080/01490450600724233

Mitchell, A. C., Phillips, A. J., Hamilton, M. A., Gerlach, R., Hollis, W. K., Kaszuba, J. P., and Cunningham, A. B. (2008). Resilience of planktonic and biofilm cultures to supercritical $\mathrm{CO}_{2}$. Journal of Supercritical Fluids 47, 318-325. 10.1016/j.supflu.2008.07.005

Mitchell, A. C., Phillips, A. J., Hiebert, R., Gerlach, R., Spangler, L. H., and Cunningham, A. B. (2009). Biofilm enhanced geologic sequestration of supercritical $\mathrm{CO}_{2}$. International Journal of Greenhouse Gas Control 3, 90-99. 10.1016/j.jjggc.2008.05.002

Morozova, D., Wandrey, M., Alawi, M., Zimmer, M., Vieth, A., Zettlitzer, M., Würdemann, H., and CO2SINK-Group. (2010). Monitoring of the microbial community composition in saline aquifers during $\mathrm{CO}_{2}$ storage by fluorescence in situ hybridisation. International Journal of Greenhouse Gas Control 4, 981-989. 10.1016/j.ijggc.2009.11.014

Mu, A., Boreham, C., Leong, H. X., Haese, R., and Moreau, J. W. (2014). Changes in the deep subsurface microbial biosphere resulting from a field-scale $\mathrm{CO}_{2}$ geosequestration experiment. Frontiers in Microbiology 5. 10.3389/fmicb.2014.00209

Nazina, T. N., Tourova, T. P., Poltaraus, A. B., Novikova, E. V., Grigoryan, A. A., Ivanova, A. E., Lysenko, A. M., Petrunyaka, V. V., Osipov, G. A., Belyaev, S. S., and Ivanov, M. V. (2001). Taxonomic study of aerobic thermophilic bacilli: descriptions of Geobacillus subterraneus gen. nov., sp nov and 
Geobacillus uzenensis sp nov from petroleum reservoirs and transfer of Bacillus stearothermophilus Bacillus thermocatenulatus, Bacillus thermoleovorans, Bacillus kaustophilus, Bacillus thermoglucosidasius and Bacillus thermodenitrificans to Geobacillus as the new combinations G-stearothermophilus, G-thermocatenulatus, G-thermoleovorans, G-kaustophilus, G-thermoglucosidasius and G-thermodenitrificans. International Journal of Systematic and Evolutionary Microbiology 51, 433-446.

Ohtomo, Y., Ijiri, A., Ikegawa, Y., Tsutsumi, M., Imachi, H., Uramoto, G. I., Hoshino, T., Morono, Y., Sakai, S., Saito, Y., Tanikawa, W., Hirose, T., and Inagaki, F. (2013). Biological $\mathrm{CO}_{2}$ conversion to acetate in subsurface coal-sand formation using a high-pressure reactor system. Frontiers in Microbiology 4. 10.3389/fmicb.2013.00361

Onstott, T. C., Phelps, T. J., Colwell, F. S., Ringelberg, D., White, D. C., Boone, D. R., McKinley, J. P., Stevens, T. O., Long, P. E., Balkwill, D. L., Griffin, W. T., and Kieft, T. (1998). Observations pertaining to the origin and ecology of microorganisms recovered from the deep subsurface of Taylorsville Basin, Virginia. Geomicrobiology Journal 15, 353-385.

Orcutt, B. N., LaRowe, D. E., Biddle, J. F., Colwell, F. S., Glazer, B. T., Reese, B. K., Kirkpatrick, J. B., Lapham, L. L., Mills, H. J., Sylvan, J. B., Wankel, S. D., and Wheat, C. G. (2013). Microbial activity in the marine deep biosphere: progress and prospects. Frontiers in Microbiology 4. 10.3389/fmicb.2013.00189

Parkes, R. J., Cragg, B., Roussel, E., Webster, G., Weightman, A., and Sass, H. (2014). A review of prokaryotic populations and processes in sub-seafloor sediments, including biosphere:geosphere interactions. Marine Geology 352, 409-425. 10.1016/j.margeo.2014.02.009

Pedersen, K., Arlinger, J., Hallbeck, L., and Pettersson, C. (1996). Diversity and distribution of subterranean bacteria in groundwater at Oklo in Gabon, Africa, as determined by $16 \mathrm{~S}$ rRNA gene sequencing. Molecular Ecology 5, 427-436. 10.1111/j.1365-294X.1996.tb00332.x

Peet, K. C., Freedman, A. J. E., Hernandez, H. H., Britto, V., Boreham, C., Ajo-Franklin, J. B., and Thompson, J. R. (2015). Microbial Growth under Supercritical $\mathrm{CO}_{2}$. Applied and Environmental Microbiology 81, 2881-2892. 10.1128/aem.03162-14

Pereira, M. O., Kuehn, M., Wuertz, S., Neu, T., and Melo, L. F. (2002). Effect of flow regime on the architecture of a Pseudomonas fluorescens biofilm. Biotechnology and Bioengineering 78, 164171. 10.1002/bit.10189

Pikuta, E. V., Hoover, R. B., and Tang, J. (2007). Microbial extremophiles at the limits of life. Critical Reviews in Microbiology 33, 183-209. 10.1080/10408410701451948

Quince, C., Lanzen, A., Davenport, R. J., and Turnbaugh, P. J. (2011). Removing noise from pyrosequenced amplicons. BMC Bioinformatics 12. 10.1186/1471-2105-12-38

Roden, E. E., and Jin, Q. (2011). Thermodynamics of microbial growth coupled to metabolism of glucose, ethanol, short-chain organic acids, and hydrogen. Applied and Environmental Microbiology 77, 1907-1909. 10.1128/aem.02425-10

Rodriguez-Ruiz, J., Belarbi, E. H., Sanchez, J. L. G., and Alonso, D. L. (1998). Rapid simultaneous lipid extraction and transesterification for fatty acid analyses. Biotechnology Techniques 12, 689-691. 10.1023/a:1008812904017

Sahl, J. W., Schmidt, R. H., Swanner, E. D., Mandernack, K. W., Templeton, A. S., Kieft, T. L., Smith, R. L., Sanford, W. E., Callaghan, R. L., Mitton, J. B., and Spear, J. R. (2008). Subsurface microbial diversity in deep-granitic-fracture water in Colorado. Applied and Environmental Microbiology 74, 143-152. 10.1128/aem.01133-07

Santillan, E. F. U., Shanahan, T. M., Omelon, C. R., Major, J. R., and Bennett, P. C. (2015). Isolation and characterization of a $\mathrm{CO}_{2}$-tolerant Lactobacillus strain from Crystal Geyser, Utah, U.S.A. Frontiers in Earth Science 3. 10.3389/feart.2015.00041 
Santillan, E. U., Kirk, M. F., Altman, S. J., and Bennett, P. C. (2013). Mineral influence on microbial survival during carbon sequestration. Geomicrobiology Journal 30, 578-592. 10.1080/01490451.2013.767396

Simoes, M., Pereira, M. O., Sillankorva, S., Azeredo, J., and Vieira, M. J. (2007). The effect of hydrodynamic conditions on the phenotype of Pseudomonas fluorescens biofilms. Biofouling 23, 249-258. 10.1080/08927010701368476

Simoes, M., Pereira, M. O., and Vieira, M. J. (2005). Effect of mechanical stress on biofilms challenged by different chemicals. Water Research 39, 5142-5152. 10.1016/j.watres.2005.09.028

Song, H., Lee, J. W., Choi, S., You, J. K., Hong, W. H., and Lee, S. Y. (2007). Effects of dissolved $\mathrm{CO}_{2}$ levels on the growth of Mannheimia succiniciproducens and succinic acid production. Biotechnology and Bioengineering 98, 1296-1304. 10.1002/bit.21530

Spilimbergo, S., Elvassore, N., and Bertucco, A. (2002). Microbial inactivation by high-pressure. Journal of Supercritical Fluids 22, 55-63. 10.1016/S0896-8446(01)00106-1

Stookey, L. L. (1970). Ferrozine - A new spectrophotometric reagent for iron. Analytical Chemistry 42, 779-781. 10.1021/ac60289a016

Watanabe, T., Furukawa, S., Hirata, J., Koyama, T., Ogihara, H., and Yamasaki, M. (2003). Inactivation of Geobacillus stearothermophilus spores by high-pressure carbon dioxide treatment. Applied and Environmental Microbiology 69, 7124-7129. 10.1128/aem.69.12.7124-7129.2003

Weber, K. A., Achenbach, L. A., and Coates, J. D. (2006). Microorganisms pumping iron: anaerobic microbial iron oxidation and reduction. Nature Reviews Microbiology 4, 752-764. 10.1038/nrmicro1490

White, A., Burns, D., and Christensen, T. W. (2006). Effective terminal sterilization using supercritical carbon dioxide. Journal of Biotechnology 123, 504-515. 10.1016/j.jbiotec.2005.12.033

Wilkins, M. J., Hoyt, D. W., Marshall, M. J., Alderson, P. A., Plymale, A. E., Markillie, L. M., Tucker, A. E., Walter, E. D., Linggi, B. E., Dohnalkova, A. C., and Taylor, R. C. (2014). $\mathrm{CO}_{2}$ exposure at pressure impacts metabolism and stress responses in the model sulfate-reducing bacterium Desulfovibrio vulgaris strain Hildenborough. Frontiers in Microbiology 5. 10.3389/fmicb.2014.00507

Wu, B., Shao, H. B., Wang, Z. P., Hu, Y. D., Tang, Y. J. J., and Jun, Y. S. (2010). Viability and metal reduction of Shewanella oneidensis MR-1 under $\mathrm{CO}_{2}$ stress: Implications for ecological effects of $\mathrm{CO}_{2}$ leakage from geologic $\mathrm{CO}_{2}$ sequestration. Environmental Science \& Technology 44, 92139218. 10.1021/es102299j

Zettlitzer, M., Moeller, F., Morozova, D., Lokay, P., Wuerdemann, H., and Grp, C. S. (2010). Reestablishment of the proper injectivity of the CO2-injection well Ktzi 201 in Ketzin, Germany. International Journal of Greenhouse Gas Control 4, 952-959. 10.1016/j.ijggc.2010.05.006

Zhang, J., Davis, T. A., Matthews, M. A., Drews, M. J., LaBerge, M., and An, Y. H. (2006). Sterilization using high-pressure carbon dioxide. Journal of Supercritical Fluids 38, 354-372. 10.1016/j.supflu.2005.05.005 
791 TOC figure. This paper integrates geomicrobiology research performed by the Center for

792 Frontiers in Subsurface Energy Security to better understand the interplay between geological 793 carbon storage (GCS) and subsurface microorganisms.

795 Figure 1. Bright-field TEM images of $\mathrm{CG}-1$ at $0.1 \mathrm{MPa} \mathrm{CO} 2(\mathrm{~A}, \mathrm{C})$ and $1.0 \mathrm{MPa} \mathrm{CO}_{2}(\mathrm{~B}, \mathrm{D})$. Arrows in: (B) show invaginations in $\mathrm{CO}_{2}$ exposed cells that may suggest cell division; (C) show the

797 intact cell wall for organisms at low $\mathrm{CO}_{2}$ exposure; (D) show the capsular material present for $798 \mathrm{CO}_{2}$ exposed cells. Modified after Santillan et al. (2015).
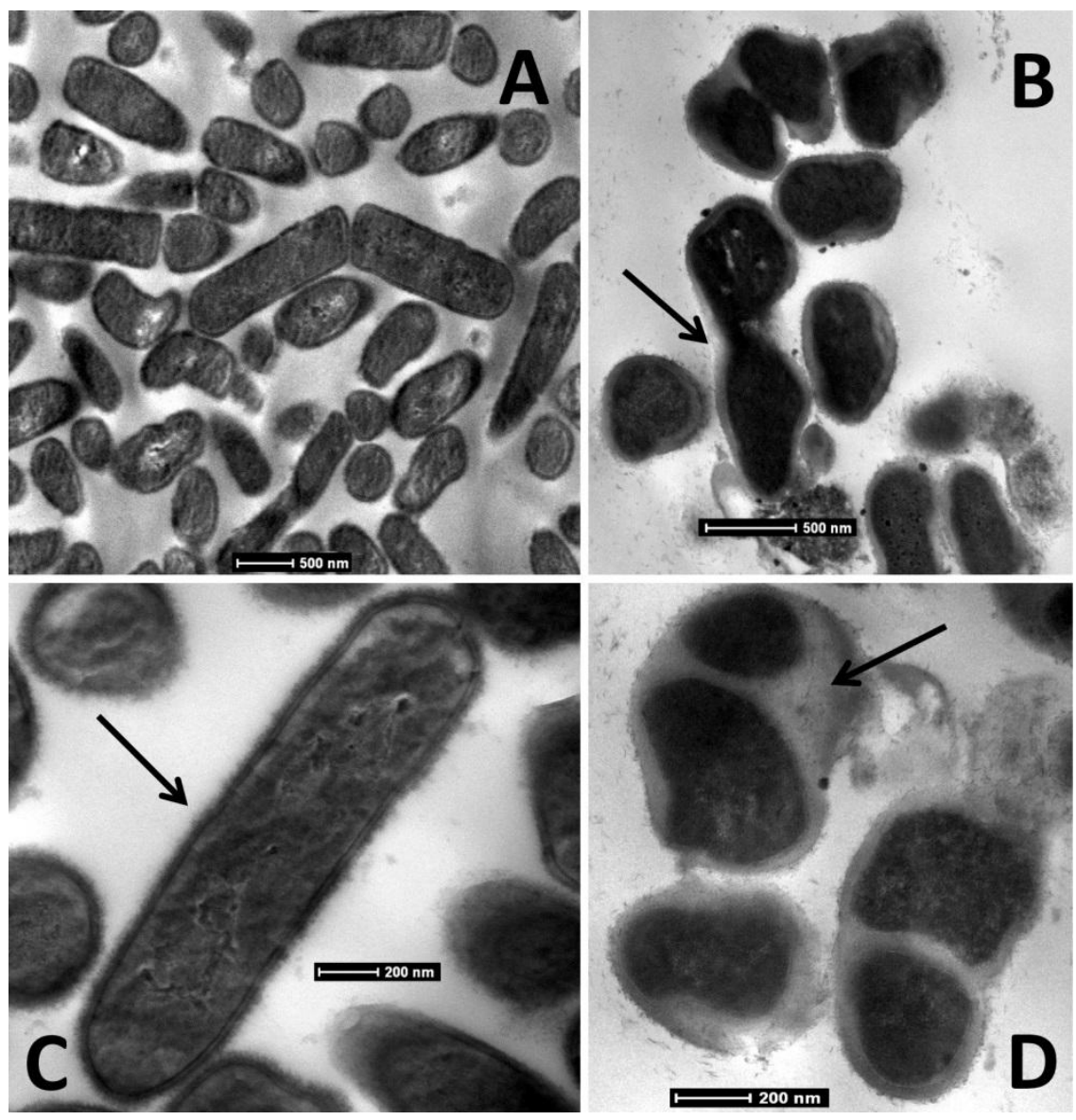
Figure 2. Variation with culture mineralogy in the abundance of culturable Shewanella

803 oneidensis MR1 cells following incubation in the presence and absence (control) of high-

804 pressure $\mathrm{CO}_{2}$. Chart modified after Santillan et al., 2013.

805

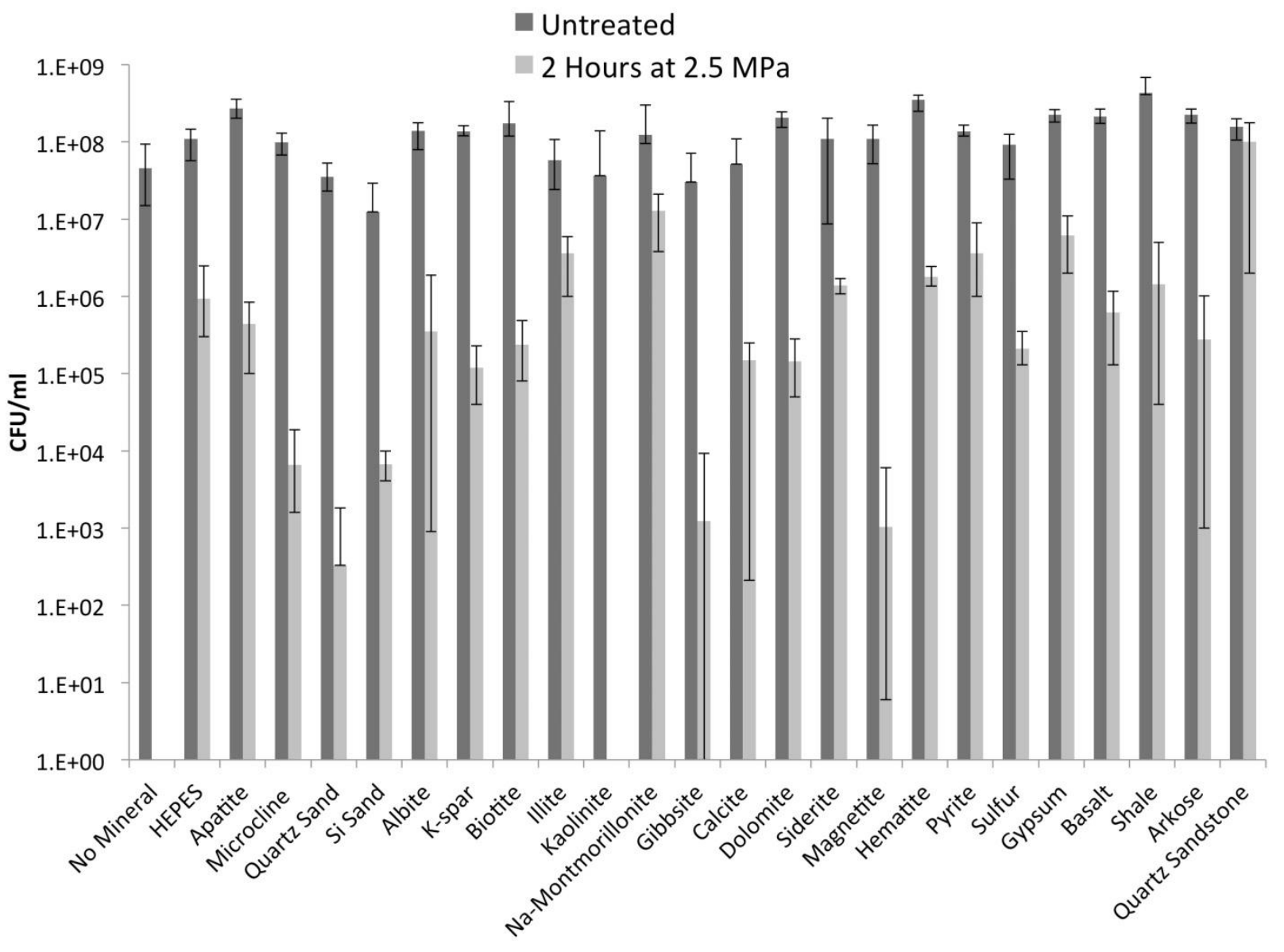

807 
Figure 3. Typical variation in hydraulic conductivity of column reactors during bioclogging experiments.

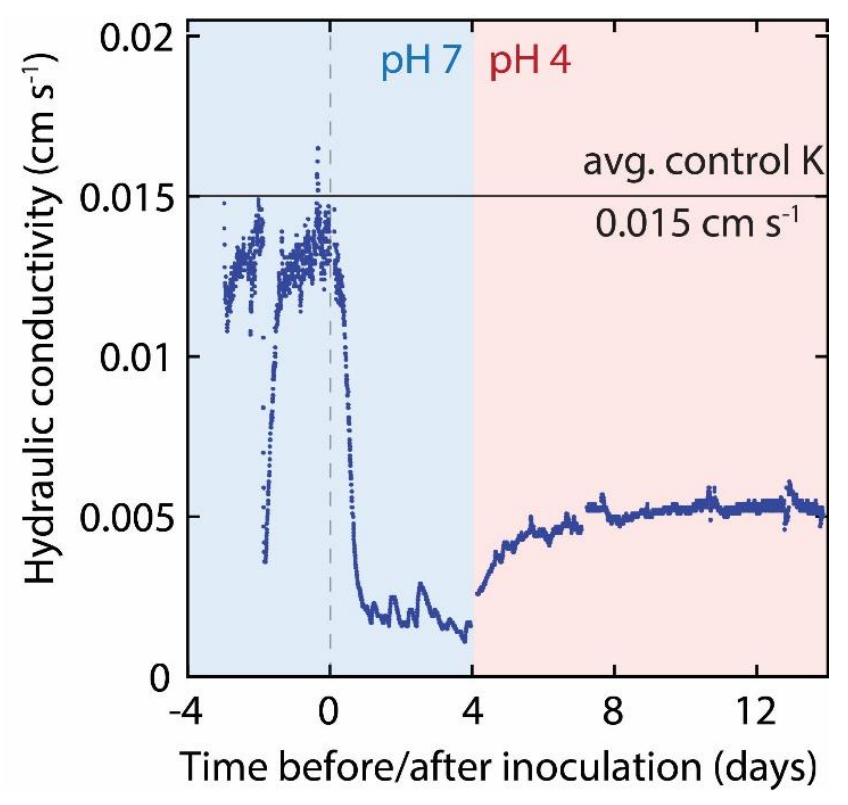

Figure 4. Average overall rate of acetate oxidation and the rate of acetate oxidation by iron reducers and sulfate reducers in the mixed-culture bioreactor experiments during the final 8 weeks of the incubations. Error bars show standard deviation.

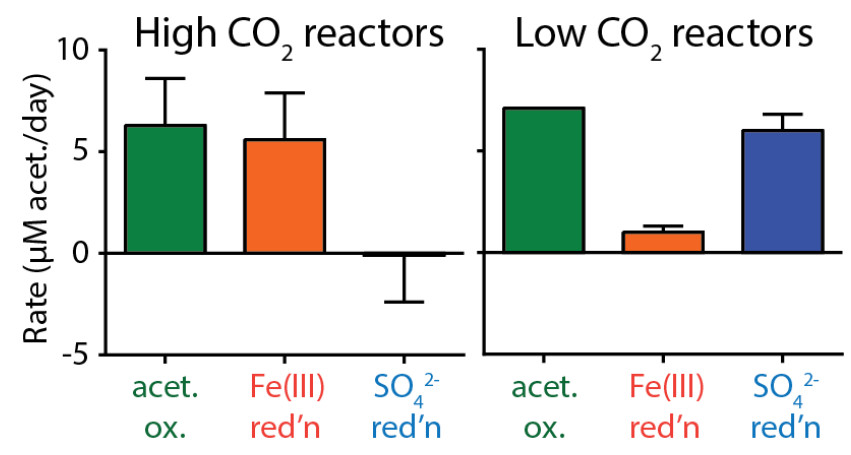


Figure 5. Change in energy available for iron reduction, sulfate reduction, and methanogenesis as a result of $\mathrm{CO}_{2}$ injection during field $\mathrm{CO}_{2}$-injection experiments. Values show the average difference between energy available prior to $\mathrm{CO}_{2}$ injection and during. Three values were averaged for the Frio Formation experiment and eight for the ZERT experiment. Error bars show standard deviation. Calculations for iron reduction considered three sources of ferric iron ( $\mathrm{Fe}(\mathrm{III}))$ : goethite $(\mathrm{FeOOH})$, hematite $\left(\mathrm{Fe}_{2} \mathrm{O}_{3}\right)$, and magnetite $\left(\mathrm{Fe}_{2} \mathrm{O}_{3}\right)$. All reactions were written on the basis of eight electron transfers with acetate or hydrogen serving as electron donors.

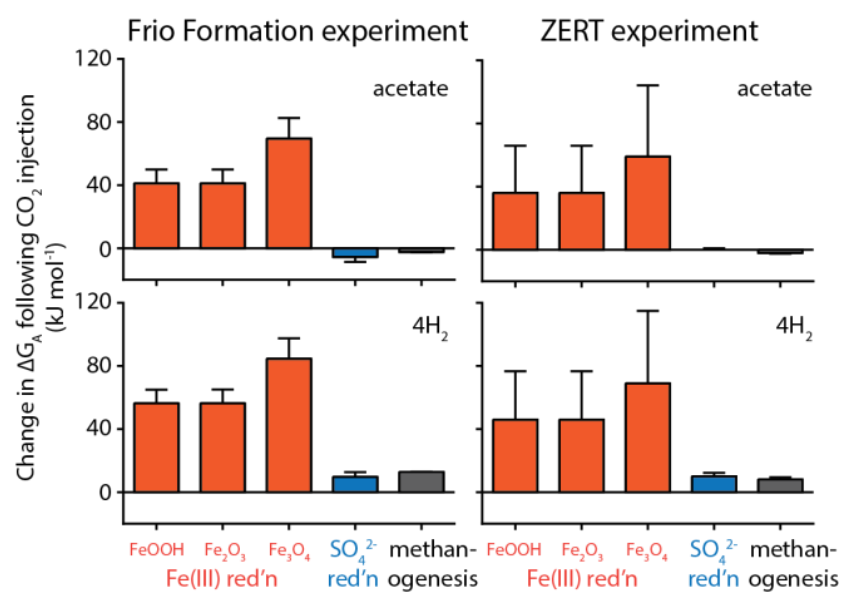

Figure 6. Average alkalinity content of effluent from the mixed-culture bioreactor experiments during the final 8 weeks of the incubations. Results are shown for biologically-active (i.e., live) bioreactors as well as corresponding sterile control reactors. Error bars show standard deviation.

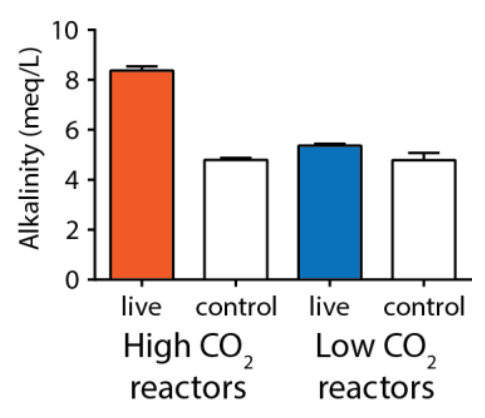

